\title{
KEMAMPUAN KOGNITIF, AFEKTIF DAN PSIKOMOTORIK SISWA SEKOLAH DASAR PADA PEMBELAJARAN IPA MENGGUNAKAN METODE INKUIRI
}

\author{
Nurul Apsari ${ }^{1}$, Sastiawati $^{2}$ \\ ${ }^{1}$ Sekolah Tinggi Keguruan dan Ilmu Pendidikan Melawi \\ ${ }^{2}$ SD Negeri 11 Nanga Pinoh \\ ${ }^{1}$ Jalan Rumah Sakit Umum Daerah Melawi KM 04 \\ ${ }^{2}$ Jalan Gelora Juang, Desa Kenual \\ nurul.apsari89@gmail.com \\ sastiawati290@gmail.com
}

\begin{abstract}
The research objective was to determine the effect of the inquiry method on student's cognitive, affective, and psychomotor abilities in science learning. The problem in this research isthe student's cognitive, affective and psychomotor abilities are not maximal in learning science.This type of research is experimental research. The design used in this research is True Experimental Designs with the type of Pretest-Posttest Control Group Designs. The research sample consisted of 50 students. The research instruments were questions (cognitive) and observation sheets (affective and psychomotor). Student's cognitive abilities in the experimental class showed a significant difference compared to the control class. Obtained $\mathrm{L}_{0}=0.4049(\alpha=0.05)$ with $\mathrm{L}_{\text {table }}=0.206$ so that the data population is not normally distributed. Then performed a difference test using $\mathrm{U}_{\text {Mann-Wihitney }}$ obtained $\mathrm{U}_{\text {tabel }}=81>\mathrm{U}_{\text {count }}=70$ so that $\mathrm{Ho}$ is rejected and $\mathrm{Ha}$ is accepted. Affective ability obtained $\mathrm{L}_{0}=0.2671(\alpha=0.05)$ with $\mathrm{L}_{\text {table }}=0.206$ so that the data population is not normally distributed. Performed the $\mathrm{U}_{\text {Mann-Whitney }}$ testobtained $\mathrm{U}_{\text {tabel }}=99<\mathrm{U}_{\text {count }}=139$ so that there is no difference in affective ability in the control and experimental classes. The normality test on psychomotor abilities obtained $\mathrm{L}_{0}=0.4049(\alpha=0.05)>\mathrm{L}_{\text {table }}=0.206$ so that the data population was not normally distributed. Furthermore, the $\mathrm{U}_{\text {Mann-Whitney }}$ test was carried out, it was obtained $U_{\text {tabel }}=99>U_{\text {count }}=89$, it was concluded that there were differences in student's psychomotor abilities in the control class and the experimental class.
\end{abstract}

Keywords: cognitive, affective, psychomotor, inquiry

\begin{abstract}
Abstrak:Tujuan penelitian adalah mengetahui pengaruh metode inkuiri terhadap kemampuan kognitif, afektif, dan psikomotorik siswa pada pembelajaran IPA. Permasalahan dalam penelitian ini adalah belum maksimalnya kemampuan kognitif, afektif dan psikomotorik siswa pada pembelajaran IPA. Jenis penelitian ini adalah penelitian eksperimen. Desain yang digunakan dalam penelitian adalahTrueExperimentalDesignsdengan tipePretest-PosttestControl GroupDesigns. Sampel penelitian berjumlah 50 siswa. Instrumen penelitian adalah soal (kognitif) dan lembar observasi (afektif dan psikomotorik). Kemampuan kognitif siswa pada kelas eksperimen menunjukkan terdapat perbedaan yang signifikan dibandingkan kelas kontrol. Diperoleh $\mathrm{L}_{0}=0,4049(\alpha=0,05)$ dengan $\mathrm{L}_{\text {tabel }}=0,206$ sehingga populasi data berdistribusi tidak normal. Kemudian dilakukan uji perbedaan menggunakan $\mathrm{U}_{\text {Mann- }}$ Wihitney yaitu $\mathrm{U}_{\text {tabel }}=81>\mathrm{U}_{\text {hitung }}=70$ sehingga Ho ditolak dan Ha diterima. Kemampuan afektif diperoleh $\mathrm{L}_{0}=0,2671(\alpha=0,05)$ dengan $\mathrm{L}_{\text {tabel }}=0,206$ sehingga populasi data berdistribusi tidak normal. Dilakukan uji $\mathrm{U}_{\text {Mann-Whitney }}$ (tingkat kepercayaan 95\%) diperoleh $\mathrm{U}_{\text {tabel }}=99<\mathrm{U}_{\text {hitung }}=139$ sehingga tidak ada perbedaan kemampuan afektif
\end{abstract}


pada kelas kontrol dan eksperimen. Uji normalitas pada kemampuan psikomotorikdiperoleh $\mathrm{L}_{0}=0,4049(\alpha=0,05)>\mathrm{L}_{\text {tabel }}=0,206$ sehingga populasi data berdistribusi tidak normal. Selanjutnyadilakukan uji $\mathrm{U}_{\text {Mann-Whitney diperoleh }}$ $\mathrm{U}_{\text {tabel }}=99>\mathrm{U}_{\text {hitung }}=89$ disimpulkanterdapat perbedaan kemampuan psikomotoriksiswa pada kelas kontrol dankelas eksperimen.

Kata Kunci: kognitif, afektif, psikomotorik, inkuiri

$\mathrm{H}$ asil belajar meliputi kemampuan kognitif, kemampuan afektif dan kemampuan psikomotorik. Ketiga kemampuan tersebut wajib dimiliki oleh peserta didik dalam proses pembelajaran khususnya pembelajaran IPA.

Kemampuan kognitif berkaitan dengan proses berpikir nyata (konkrit) sampai menuju konsep yang bersifat abstrak dan logis (Ibda, 2015:27). Kemampuan afektif meliputi aspek kerjasama, kedisiplinan, keberanian, toleransi dan kesungguhan (Hendarni, 2013: 45). Kemampuan psikomotorik merupakan hasil belajar yang tampak dalam bentuk keterampilan (skill) dan kemampuan bertindak individu (Sudjana, 2013). Aspek psikomotorik yang diamati meliputi menirukan, memanipulasi, melakukan/ pengalamiahan dan artikulasi (Hendarni, 2013: 46).Namun pada kenyatannya, guru masih dominan hanya mengukur kemampuan kognitif peserta didik sebagai acuan keberhasilan dalam proses pembelajaran.

Peran pendidikan salah satunya adalah memberikan pengaruh positif pada kemampuan adaptasi peserta didik terhadap lingkungannya sehingga kelak dapat memberikan kebermanfaatan yang sangat besar kepada masyarakat (Trianto, 2011). Dengan demikian, diperlukan pemilihan metode yang tepat dalam proses pembelajaran IPA yang sesuai agar peran pendidikan dalam terlaksana secara maksmal.

Penempatan siswa sebagai subjek pada proses belajar mengajar memberikan kontribusi yang besar terhadap suasana dan metode yang digunakan dalam pembelajaran (Anam, 2015: 7). Metode inkuiri memungkinkan pembelajaran terpusat pada siswa (studentcenter) dikarenakan siswa memiliki kesempatan yang sama untuk dapat terlibat secara langsung dalam proses pembelajaran. Siswa juga sadar terkait pengetahuan yang diperoleh dari proses pembelajaran tersebut (Aqib, 2016: 83). Metode inkuiri juga dapat melatih siswa berpikir secara kritis untuk dapat memecahkan masalah (Hamalik dalam Arantika, 2014: 3).

Sintaks metode inkuiri dalam pembelajaran antara lain: merumuskan 
pertanyaan, merumuskan hipotesis, perencanaan dan pelaksanaan eksperimen sederhana, presentasi hasil eksperimen dan membuat kesimpulan berdasarkan hasil eksperimen (Susanto, 2016: 176).

Pemilihan metode inkuiri pada penelitian ini dikarenakan sintaks pada metode inkuiri memberikan kesempatan kepada siswa untuk melakukan penyelidikan sederhana dan kemudian membuat kesimpulan berdasarkan penyelidikan tersebut (Alberta dalam Susanto, 2016: 172).Pada metode inkuiri juga memungkinkan siswa untuk berperan menjadi ilmuan (Kurniasih, 2016: 113).

Metode inkuiri merupakan solusi yang digunakan untuk meningkatkan kualitas pembelajaran yang dapat diukur pada ranah kognitif, afektif dan psikomotorik. Tujuan dalam penelitian ini adalah untuk mengetahui perbedaan kemampuan kognitif, afektif dan psikomotorik siswa sekolah dasar antara kelas kontrol (menggunakan metode konvensional) dan kelas eksperimen (menggunakan metode inkuiri) pada pembelajaran IPA.

\section{METODE PENELITIAN}

Jenis penelitian ini adalah penelitian eksperimen. Desain yang digunakan dalam penelitian adalah TrueExperimentalDesignsdengan tipe
Pretest-Posttest Control Group Designs dengan pola desainnya, yaitu:

Tabel 1. Pretest-PosttestControl Group Designs

\begin{tabular}{ccccc}
\hline Kelas & Subjek & $\begin{array}{c}\text { Pre- } \\
\text { test }\end{array}$ & Perlakuan & $\begin{array}{c}\text { Post- } \\
\text { test }\end{array}$ \\
\hline $\begin{array}{l}\text { Ekspe- } \\
\text { rimen } \\
\text { Kontrol }\end{array}$ & $\mathrm{R}$ & $\mathrm{O}_{1}$ & $\mathrm{X}$ & $\mathrm{O}_{2}$ \\
\hline
\end{tabular}

Keterangan:

$\mathrm{R}$ : Pengambilan sampel secara acak $\mathrm{O}_{1}$ : Test awal (pre-test) dikelas eksperimen

$\mathrm{O}_{2}$ : Test akhir (post-test) dikelas eksperime

$\mathrm{O}_{3}$ : Test awal (pre-test) dikelas kontrol $\mathrm{O}_{4}$ : Test akhir (post-test) dikelas kontrol $\mathrm{X}:$ Perlakuan (treament) yaitu menggunakan metode inkuiri.

Sugiyono (2011: 112)

Populasidan sampel penelitian adalahsiswa-siswikelas V Sekolah Dasar di Kecamatan Nanga Pinohdengan jumlah 50 siswa.Variabelbebasdalampenelitianadalah metodeinkuiri sedangkan variabelterikat adalah kemampuan kognitif, afektif dan psikomotorik siswa sekolah dasar.Teknik pengambilan sampel dalam penelitian adalah probability sampling (pengambilan sampel secara random atau acak) dengan jenis simplerandom sampling.

Teknik pengumpulan data adalah tes dan non tes. Teknik tes untuk mengukur kemampuan kognitif dan non tes untuk mengukur kemampuan afektif dan psikomotorik.Instrumen penelitian adalah soal uraian untuk kemampuan kognitif dan lembar observasi untuk kemampuan afektif 
dan psikomotorik. Instrumen penelitian divalidasi isi untuk mengetahui kelayakan instrumen yang digunakan dalam penelitian, (Purwanto, 2011: 120). Instrumen penelitian divalidasi oleh ahli dan dinyatakan valid. Reliabilitas instrumen bertujuan untuk mengetahui derajat konsistensi instrumen,menggunakan rumus Kuder Richadson 20 (KR-20), Purwanto (2011: 169), seperti berikut ini :
Keterangan:

$$
\begin{array}{ll}
\mathrm{r}_{11} & =\text { reliabilitasinstrumen } \\
\mathrm{n} & =\text { banyaknyabutirsoal } \\
\mathrm{s}_{\mathrm{t}}^{2} & =\text { varians total } \\
\mathrm{p} & =\text { proporsiskor yang diperoleh } \\
\mathrm{q} & =\text { proporsiskor maksimum dikurangi }
\end{array}
$$

skor yang diperoleh.

Hasil reliabilitas instrumen adalah $r_{\text {hitung }}=$ $0,86>\mathrm{r}_{\text {tabel }}=0,7 \quad$ sehingga instrumen penelitian dinyatakan reliabel dan layak

\begin{tabular}{|c|c|c|c|c|}
\hline 2 & Mengidenti-fikasisifat-sifatcahaya & $\mathrm{C} 1, \mathrm{C} 4$ & 1,10 & 4,8 \\
\hline 3 & Menjelaskan sifat-sifat cahaya & $\mathrm{C} 2$ & $3,13,12$ & $1,9,10,15$ \\
\hline 4 & $\begin{array}{l}\text { Memberikan contoh benda yang } \\
\text { berhubu-ngan dengan sifat-sifat } \\
\text { cahaya }\end{array}$ & $\mathrm{C} 2$ & $2,8,14$ & $3,4,6,11$ \\
\hline 5 & $\begin{array}{l}\text { Melakukanpercobaan sifat- } \\
\text { sifatcahaya }\end{array}$ & C3 & $5,6,7$ & 12,13 \\
\hline 6 & Menyimpul-kanmateri pembelajaran & C5, C6 & 11,15 & 2,14 \\
\hline
\end{tabular}
digunakan.

$$
r_{11}=\left(\frac{n}{n-1}\right) \quad\left(\frac{s t^{2}-\Sigma p q}{s t^{2}}\right)
$$

\begin{tabular}{|c|c|c|}
\hline No & $\begin{array}{c}\text { Sikap Yang } \\
\text { Diamati }\end{array}$ & Indikator \\
\hline 1 & Kerjasama & $\begin{array}{l}\text { a. Berdiskusi secara aktif dalam kelompok } \\
\text { b. Saling membantu anggota kelompok yang mengalami kesulitan dalam menyelesaikan } \\
\text { soal/percobaan maupun saat diskusi kelompok } \\
\text { c. Memprioritaskan kepentingan kelompok diatas kepentingan individu } \\
\text { d. Pembagian tugas dan tanggungmjawab secara adil pada semua anggota kelompok dalam } \\
\text { menyelesaikan soal/percobaan maupun saat diskusi kelompok }\end{array}$ \\
\hline 2 & Kedisiplinan & $\begin{array}{l}\text { a. Tepat waktu mengikuti pembelajaran } \\
\text { b. Taat pada instruksi yang diberikan guru dalam proses pembelajaran } \\
\text { c. Patuh pada aturan yang berlaku di kelas ketika proses pembelajaran berlangsung } \\
\text { d. Pengumpulan tugas dilakukan tepat waktu sesuai instruksi dari guru }\end{array}$ \\
\hline 3 & Keberanian & $\begin{array}{l}\text { a. Keberanian dalam mempresentasikan hasilkerja selama proses pembelajaran } \\
\text { b. Keberanian memberikan pendapat dan saran ketika diskusi } \\
\text { c. Keberanian menyampaikan sanggahan terhadap pernyataan atau jawaban saat diskusi }\end{array}$ \\
\hline
\end{tabular}

Tabel 2. Kisi-kisi soal kemampuan kognitif

\begin{tabular}{ccccc}
\hline \multirow{2}{*}{ No } & Indikator & Tingkat & \multicolumn{2}{c}{ Nomor Soal } \\
& & Kognitif & Pretest & Postest \\
\hline 1 & Menyebutkansifat-sifatcahaya & $\mathrm{C} 1$ & 4,9, & 5,7
\end{tabular}

Tabel 3. Kisi-kisi lembar observasi kemampuan afektif

40| J P D, p - I S S N : 2252-8156, e - I S S N : $2579-3993$ 


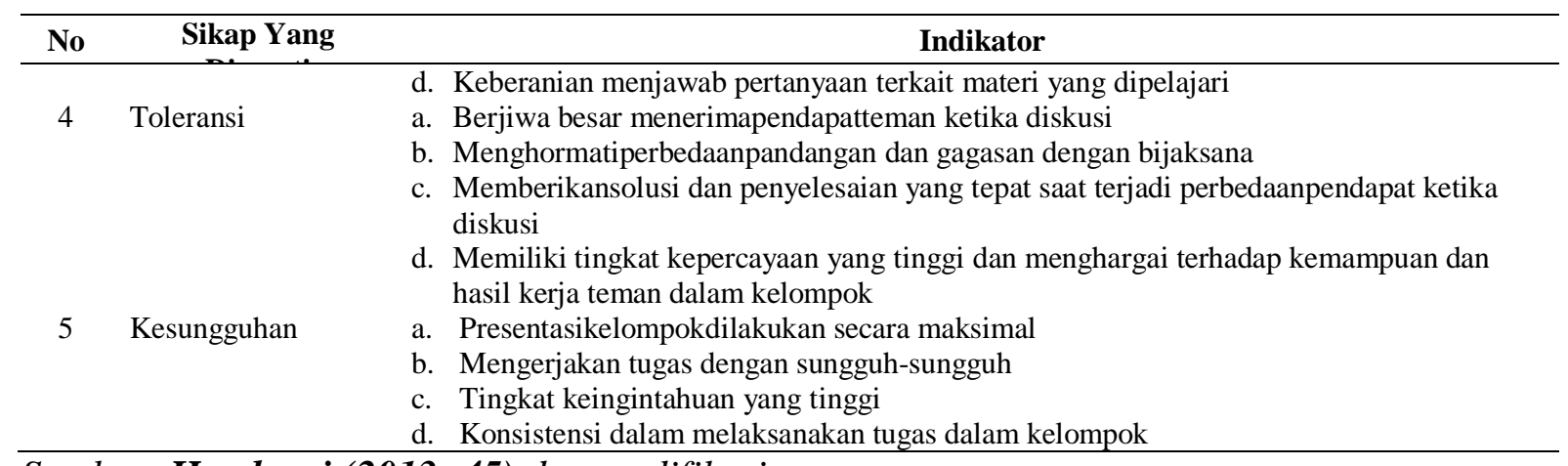

Sumber: Hendarni (2013: 45) dan modifikasi

Tabel 4. Kisi-kisi lembar observasi kemampuan psikomotorik

\begin{tabular}{|c|c|c|}
\hline No & $\begin{array}{l}\text { Keterampilan } \\
\text { yang diamati }\end{array}$ & Indikator \\
\hline 1 & Menirukan & $\begin{array}{l}\text { a. Melakukan percobaan sesuai dengan instruksi yang diberikan guru serta pedoman } \\
\text { percobaan } \\
\text { b. Mendapatkan hasil percobaan yang sesuai dengan teori dan pedoman percobaan }\end{array}$ \\
\hline 2 & Memanipulasi & $\begin{array}{l}\text { a. Mempersiapkan dan memodifikasi alat dan bahan yang digunakan dalam percobaan } \\
\text { b. Membandingkan hasil diskusi kelompok dengan kelompok yang lain }\end{array}$ \\
\hline 3 & $\begin{array}{l}\text { Melakukan/ } \\
\text { Pengalamiahan }\end{array}$ & $\begin{array}{l}\text { a. Mengidentifikasi kesesuaian antara hasil hasil percobaan dengan kebenaran teori } \\
\text { b. Menemukan intisari pembelajaran sesuai dengan percobaan yang dilakukan }\end{array}$ \\
\hline 4 & Artikulasi & $\begin{array}{l}\text { a. Menyampaikan hasil temuan dari hasil percobaan maupun hasil diskusi secara sistematis } \\
\text { dan jelas } \\
\text { b. Mampu menjelaskan dan menjawab pertanyaan terkait hasil percobaan dan diskusi dengan } \\
\text { cepat dan jelas }\end{array}$ \\
\hline
\end{tabular}

Teknik analisis data yang digunakan dalam penelitian yaitu uji Liliefors untuk menguji normalitas data dan Uji $U_{\text {Man-Whitney }}$ untuk menguji apakah terdapat perbedaan kemampuan kognitif, afektif dan psikomotorik siswa pada kelas kontrol dan eksperimen menggunakan metode inkuiri.

Hipotesis dalam penelitian ini antara lain : (a) terdapat perbedaan yang signifikan antara kemampuan kognitif siswa pada kelas kontrol dan kelas eksperimen; (b) terdapat perbedaan yang signifikan antara kemampuan afektif siswa pada kelas kontrol dan kelas eksperimen; (c) terdapat perbedaan yang signifikan 41| J P D, p- I S S N : 2252-8156, e - I S S N : $2579-3993$ antara kemampuan psikomotorik siswa pada kelas kontrol dan kelas eksperimen.

\section{HASIL DAN PEMBAHASAN}

Penelitian dilakukan selama 6 minggu atau sebanyak 4 kali tatap muka pada proses belajar mengajar dan 2 kali tes (sebelum dan sesudah proses pembelajaran) masing-masing pada kelas kontrol dan kelas eksperimen. Pada kelas kontrol, pembelajaran IPA menggunakan metode konvensional dan pada kelas eksperimen menggunakan metode inkuiri.

Hasil penelitian menunjukkan perbedaan antara proses pembelajaran kelas kontrol dan eksperimen pada 
kemampuan kognitif dan psikomotorik dan pada kemampuan afektif tidak terlihat perbedaan yang signifikan antara kelas kontrol dan kelas eksperimen. Pada kelas kontrol, siswa dominan pasif dalam proses pembelajaran dan pembelajaran sangat terpusat pada guru (teachercenter). Pada kelas eksperimen yaitu menggunakan metode inkuiri, siswa difasilitasi untuk dapat berperan aktif dalam proses pembelajaran. Pembelajaran terpusat pada siswa (studentcenter).

Kemampuan kognitif siswa pada kelas kontrol dan eksperimen dapat dilihat pada tabel dibawah ini.

Tabel 5. Kemampuan kognitif siswa

\begin{tabular}{lcccc}
\hline \multicolumn{1}{c}{ Ket } & \multicolumn{2}{c}{$\begin{array}{c}\text { Kelas Eksperimen } \\
\text { Pre- } \\
\text { test }\end{array}$} & Post-test & \multicolumn{2}{c}{ Kelas Kontrol } \\
& Pretest & Posttest \\
\hline Rata-rata & 47,06 & 80 & 48,74 & 54 \\
$\begin{array}{l}\text { Nilai } \\
\text { Nilai }\end{array}$ & 73 & 93 & 67 & 73 \\
$\begin{array}{l}\text { Tertinggi } \\
\text { Nilai } \\
\text { Terendah }\end{array}$ & 13 & 67 & 13 & 33 \\
$\begin{array}{l}\text { Persentase } \\
\text { Ketuntasan }\end{array}$ & $29,41 \%$ & $100 \%$ & $42,11 \%$ & $47,37 \%$ \\
$\begin{array}{l}\text { Persentase } \\
\text { Siswa }\end{array}$ & $73,68 \%$ & $0 \%$ & $57,89 \%$ & $52,63 \%$ \\
$\begin{array}{l}\text { Tidak } \\
\text { Tuntas }\end{array}$ & & & & \\
\hline
\end{tabular}

Berdasarkan Tabel 5, maka dapat disimpulkan bahwa pembelajaran IPA dengan menggunakan metode inkuiri pada kelas eksperimen memperoleh rata-rata nilai dan persentase ketuntasan lebih tinggi dibandingkan kelas kontrol. Kemampuan kognitif siswa pada kelas eksperimen menunjukkan terdapat perbedaan yang signifikan dibandingkan kelas kontrol.
Diperoleh $\mathrm{L}_{0}=0,4049(\alpha=0,05)$ dengan $\mathrm{L}_{\text {tabel }}=0,206$ sehingga populasi data berdistribusi tidak normal. Kemudian dilakukan uji perbedaan menggunakan $\mathrm{U}_{\text {Mann-Wihitney }}$ yaitu $\mathrm{U}_{\text {tabel }}=81>\mathrm{U}_{\text {hitung }}=70$ sehingga Ho ditolak dan Ha diterima.

Pembelajaran IPA menggunakan metode inkuiri pada kelas eksperimen memberikan kesempatan kepada siswa untuk menemukan sendiri jawaban atas pertanyaan sesuai indikator pembelajaran. Guru hanya berperan sebagai fasilitator sehingga siswa menjadi lebih paham kedalaman materi melalui kegiatan percobaan yang dirancang dalam pembelajaran menggunakan metode inkuiri. Sejalan dengan penelitian bahwa pemahaman kimia mengalami peningkatan menggunakan pembelajaran inkuiri sebesar 82,1\% (Sahputra, 2014: 193-197).

Kemampuan afektif siswa pada kelas kontrol dan eksperimen dapat dilihat pada tabel dibawah ini.

\section{Tabel 6. Kemampuan afektif siswa}

\begin{tabular}{|c|c|c|c|c|}
\hline No & $\begin{array}{l}\text { Sikap Yang } \\
\text { Diamati }\end{array}$ & Indikator & $\begin{array}{c}\text { Kelas } \\
\text { Kontrol }\end{array}$ & $\begin{array}{c}\text { Kelas } \\
\text { Eks }\end{array}$ \\
\hline \multirow[t]{4}{*}{1} & Kerjasama & $\mathrm{a}$ & 70 & 75 \\
\hline & & b & 70 & 75 \\
\hline & & c & 70 & 75 \\
\hline & & d & 65 & 70 \\
\hline \multirow[t]{4}{*}{2} & Kedisiplinan & $\mathrm{a}$ & 75 & 85 \\
\hline & & $\mathrm{b}$ & 75 & 90 \\
\hline & & $\mathrm{c}$ & 75 & 90 \\
\hline & & d & 75 & 80 \\
\hline \multirow[t]{3}{*}{3} & Keberanian & $\mathrm{a}$ & 65 & 75 \\
\hline & & b & 70 & 75 \\
\hline & & c & 68 & 75 \\
\hline
\end{tabular}

42| J P D, p - I S S N : 22 252-8156, e - I S S N : $2579-3993$ 


\begin{tabular}{|c|c|c|c|c|}
\hline No & $\begin{array}{c}\text { Sikap Yang } \\
\text { Diamati }\end{array}$ & Indikator & $\begin{array}{c}\text { Kelas } \\
\text { Kontrol }\end{array}$ & $\begin{array}{c}\text { Kelas } \\
\text { Eks }\end{array}$ \\
\hline \multirow{5}{*}{4} & & $\mathrm{~d}$ & 65 & 75 \\
\hline & Toleransi & $\mathrm{a}$ & 70 & 80 \\
\hline & & $\mathrm{b}$ & 65 & 80 \\
\hline & & $\mathrm{c}$ & 70 & 85 \\
\hline & & $\mathrm{d}$ & 70 & 85 \\
\hline \multirow[t]{5}{*}{5} & Kesungguhan & $\mathrm{a}$ & 70 & 90 \\
\hline & & $\mathrm{b}$ & 75 & 82 \\
\hline & & $\mathrm{c}$ & 75 & 85 \\
\hline & & $\mathrm{d}$ & 75 & 90 \\
\hline & Rata-rata & & 70,65 & 80.85 \\
\hline
\end{tabular}

diketahui bahwa terdapat perbedaan antara kemampuan afektif pada kelas kontrol dan kelas eksperimen namun hasilnya tidak begitu signifikan. Setelah dilakukan uji secara statistik maka diketahui bahwa kemampuan afektif diperoleh $\mathrm{L}_{0}=0,2671$ $(\alpha=0,05)$ dengan $\mathrm{L}_{\text {tabel }}=0,206$ sehingga populasi data berdistribusi tidak normal. Dilakukan uji $\mathrm{U}_{\text {Mann-Whitney (tingkat }}$ kepercayaan 95\%) diperoleh $\mathrm{U}_{\text {tabel }}=99<$ $\mathrm{U}_{\text {hitung }}=139$ sehingga tidak ada perbedaan yang signifikan kemampuan afektif pada kelas kontrol dan eksperimen.

Metode inkuiri pada pembelajaran IPA dapat mendorong siswa untuk menjadi lebih disiplin dan fokus dalam proses pembelajaran, namun hasil penelitian menunjukkan bahwa perbedaan yang terjadi antara kelas kontrol dan eksperimen tidak terjadi secara signifikan. Adapun penyebabnya dikarenakan masih adanya siswa yang belum maksimal dalam bekerja sama dalam kelompok dan masih kurangnya keberanian siswa dalam 43 | J P D, p - I S S N : 2252-8156, e - I S S N : $2579-3993$ mempresentasikan hasil pembelajaran pada saat diskusi.

Kemampuan psikomotorik siswa pada kelas kontrol dan eksperimen dapat dilihat pada tabel dibawah ini.

\section{Tabel 7. Kemampuan psikomotorik} siswa

\begin{tabular}{|c|c|c|c|c|}
\hline No & $\begin{array}{l}\text { Keterampilan } \\
\text { yang diamati }\end{array}$ & Indikator & $\begin{array}{c}\text { Kls } \\
\text { Kontrol }\end{array}$ & $\begin{array}{l}\text { Kls } \\
\text { Eks }\end{array}$ \\
\hline \multirow[t]{2}{*}{1} & Menirukan & $\mathrm{a}$ & 60 & 85 \\
\hline & & $\mathrm{b}$ & 65 & 89 \\
\hline \multirow[t]{2}{*}{2} & Memanipulasi & $\mathrm{a}$ & 60 & 85 \\
\hline & & b & 60 & 85 \\
\hline \multirow[t]{2}{*}{3} & Melakukan/ & $\mathrm{a}$ & 50 & 95 \\
\hline & Pengalamiahan & $b$ & 55 & 87 \\
\hline \multirow[t]{2}{*}{4} & Artikulasi & $\mathrm{a}$ & 65 & 80 \\
\hline & & $\mathrm{b}$ & 67 & 82 \\
\hline & Rata-rata & & 60,25 & 85,63 \\
\hline
\end{tabular}

Uji normalitas pada kemampuan psikomotorikdiperoleh $\mathrm{L}_{0}=0,4049(\alpha=$ $0,05)>\mathrm{L}_{\text {tabel }}=0,206$ sehingga populasi data berdistribusi tidak normal. Selanjutnyadilakukan uji $\mathrm{U}_{\text {Mann-Whitney }}$ diperoleh $\quad \mathrm{U}_{\text {tabel }}=99>\mathrm{U}_{\text {hitung }}=$ 89disimpulkanterdapat perbedaan kemampuan psikomotoriksiswa pada kelas kontrol dan kelas eksperimen.

Kemampuan psikomotorik siswa menggunakan metode inkuiri menunjukkan adanya perbedaan yang signifikan antara kelas kontrol dan kelas eksperimen. Pembelajaran IPA menggunakan metode inkuiri memberikan peluang kepada siswa untuk ikut aktif dalam proses pembelajaran. Siswa mendapatkan pengalaman belajar melalui kegiatan percobaan, memahami prosedur dalam 
percobaan, mengamati hasil percobaan dan dapat menyimpulkan hasil percobaan yang telah dilakukan. Metode inkuiri dapat melatih kemampuan psikomotorik siswa dalam pembelajaran IPA. Sesuai dengan penelitian yang menunjukkan penggunaan metode inkuiri terbimbing pada aspek psikomotorik sebesar 86,03 \% dengan kategori sangat kuat (Patimapat, dkk, 2019:9-20).

\section{SIMPULAN}

Berdasarkan hasil penelitian dapat disimpulkan bahwa terdapat pengaruh yang signifikan pada kemampuan kognitif dan psikomotorik siswa pada pembelajaran IPA meggunakan metode inkuiri. Sedangkan pada kemampuan afektif diperoleh hasil bahwa tidak terdapat perbedaan yang signifikan antara kelas kontrol dan kelas eksperimen.

\section{DAFTAR PUSTAKA}

Anam, K. (2015). Pembelajaran Berbasis Inkuiri Metode dan Aplikasi. Yogyakarta: Pustaka Pelajar.

Aqib, Z. (2016). Kumpulan Metode Pembelajaran Kreatif dan Inovatif. Bandung: Satu Nusa.

Arantika, J. (2014). Pengaruh Inkuiri Berbantuan Pictorial Riddle Terhadap Kemampuan Berpikir Kritis pada Materi Koloid di SMA.
Jurnal Pendidikan dan Pembelajaran, vol. 10, Jilid. 3. Hal. $1-3$

Hendarni. (2013). Peningkatan Hasil Belajar Membaca Peta pada Pembelajaran Tema Indahnya Negeriku dengan Menggunakan Media Peta Puzzlepada Siswa Kelas IV SD Negeri 1 Gumukmas Tahun Pelajaran 2013/2014. Universitas Lampung Fakultas Keguruan dan Ilmu Pendidikan Program Studi Pendidikan Guru Sekolah Dasar.

Ibda, F. (2015). Perkembangan Kognitif : Teori Jean Piaget. Intelektualita, Volume 3, Nomor 1, Januari-Juni 2015, 27-38.

Kuniasih. (2016). Ragam Pengembangan Model Pembelajaran Untuk Meningkatkan Profesionalitas Guru. Yogyakarta: Kata Pena.

Patimapat, M., Duda, H. J., \& Supiandi, M.I. (2019). Efektivitas model pembelajaran inkuiri terbimbing melalui metode demonstrasi terhadap hasil belajar psikomotorik siswa. JPBIO (Jurnal Pendidikan Biologi), 4(1): 09-20.

Purwanto. (2011). Evaluasi Hasil Belajar. Yogyakarta: Pustaka Pelajar.

Sahputra, R. (2014). Pembelajaran dengan Model Inkuiri pada Materi Kimia Sekolah Menengah Atas. Jurnal 44| J P D, p - I S S N : 2252-8156, e - I S S N : $2579-3993$ 
Pendidikan Dasar, Volume 2,

Nomor 2, Desember 2014, Hal. 193197.

Sudjana. (2015). Metoda Statistika. Bandung: Tarsito.

Sugiono. (2016). Metode Penulisan Pendidikan Pendekatan Kuantitaif, Kualitatif, dan $R$ \& D. Bandung: Alfabeta.

Susanto, A. (2016). Teori Belajar dan Pembelajaran di Sekolah Dasar. Jakarta: Prenan media Group.

Trianto. (2011). Mendesain model pembelajaran inovatif-progresif. Jakarta: Kencana Prenada Media. 